\title{
Control of nitrous oxide emission from Chironomus plumosus larvae by nitrate and temperature
}

\author{
Peter Stief,a,b,* Lubos Polerecky, ${ }^{a}$ Morten Poulsen, ${ }^{b}$ and Andreas Schrammb
}

a Max Planck Institute for Marine Microbiology, Microsensor Group, Bremen, Germany

b Department of Biological Sciences, Microbiology, Aarhus University, Aarhus, Denmark

\begin{abstract}
Aquatic invertebrates that ingest large numbers of bacteria produce substantial amounts of the greenhouse gas $\mathrm{N}_{2} \mathrm{O}$ because of incomplete denitrification in their anoxic gut. We investigated the influence of two key environmental factors, temperature and $\mathrm{NO}_{3}^{-}$availability, on $\mathrm{N}_{2} \mathrm{O}$ emission from larvae of Chironomus plumosus in field and laboratory experiments. Larvae collected from lake sediments emitted between 2 and 73 pmol $\mathrm{N}_{2} \mathrm{O}$ ind. ${ }^{-1} \mathrm{~h}^{-1}$ during the warm season, but took up maximally -27 pmol $\mathrm{N}_{2} \mathrm{O}$ ind.$^{-1} \mathrm{~h}^{-1}$ during winter. Larvae kept in laboratory microcosms emitted between 14 and 122 pmol $\mathrm{N}_{2} \mathrm{O}$ ind. ${ }^{-1} \mathrm{~h}^{-1}$, and $\mathrm{N}_{2} \mathrm{O}$ uptake was never observed. For both types of larvae, the rate of $\mathrm{N}_{2} \mathrm{O}$ emission was stimulated by temperature (when the $\mathrm{NO}_{3}^{-}$ concentration in the water column was higher than $25-50 \mu \mathrm{mol} \mathrm{L}{ }^{-1}$ ) and by $\mathrm{NO}_{3}^{-}$(when the temperature was higher than $4-10^{\circ} \mathrm{C}$ ). Modeling based on experimentally determined ventilation parameters and sedimentary $\mathrm{O}_{2}$ and $\mathrm{NO}_{3}^{-}$turnover rates predicted that $\mathrm{NO}_{3}^{-}$concentrations inside the burrow and in the sediment surrounding the burrow fluctuated and were on average lower than those in the water column. In contrast, $\mathrm{NO}_{3}^{-}$ concentrations measured in the gut and hemolymph of the microcosm-incubated larvae were at least as high as in the water column. This suggests that $\mathrm{N}_{2} \mathrm{O}$ emission from $C$. plumosus larvae is controlled by $\mathrm{NO}_{3}^{-}$availability in the water column, but is decoupled, by a hitherto unknown mechanism, from $\mathrm{NO}_{3}^{-}$present in the immediate surroundings of the larva.
\end{abstract}

Nitrous oxide emission from freshwater sediment is enhanced in the presence of benthic invertebrates (Svensson 1998). Recently, it has been discovered that a considerable fraction of this enhancement is due to $\mathrm{N}_{2} \mathrm{O}$ production directly associated with the animals (Stief et al. 2009). Filter- and deposit-feeding aquatic invertebrates (FD feeders) in particular emit substantial amounts of this potent greenhouse gas. All of the FD-feeding species that have so far been proven to emit $\mathrm{N}_{2} \mathrm{O}$ often occur at abundances of several thousand to tens of thousands of individuals per square meter (Wright et al. 1981; Svensson and Leonardson 1996; Ricciardi et al. 1997). Hence, these animals have the potential to significantly enhance the rate of $\mathrm{N}_{2} \mathrm{O}$ emission from aquatic ecosystems. $\mathrm{N}_{2} \mathrm{O}$ is produced in the gut of FD feeders because of incomplete denitrification by bacteria that have been ingested together with food particles (Stief et al. 2009). Animal guts in which denitrification and concomitant production of $\mathrm{N}_{2} \mathrm{O}$ occur are characterized by anoxia and the availability of $\mathrm{NO}_{3}^{-}$ and dissolved organic substrates (Horn et al. 2003; Stief and Eller 2006). Thus, many of the ingested soil and sediment bacteria experience a shift from oxic conditions in their natural environment to anoxic conditions in the animal gut, which induces denitrification and $\mathrm{N}_{2} \mathrm{O}$ production (Horn et al. 2003; Stief et al. 2009).

Although the link between the $\mathrm{N}_{2} \mathrm{O}$ emission and the feeding traits of the animals involved has been established, the question remains as to what extent environmental factors control the rate of $\mathrm{N}_{2} \mathrm{O}$ emission from aquatic invertebrates. In this context, the influence of the environmental factors must be considered at two scales: macro-

\footnotetext{
*Corresponding author: pstief@mpi-bremen.de
}

scopic, corresponding to the animal's habitat at large, and microscopic, representing the immediate surroundings of the animal and even body compartments of the animal itself. The availability of $\mathrm{NO}_{3}^{-}$in the animal's macroenvironment is largely determined by the type of ecosystem in which it lives, the degree of pollution with $\mathrm{NO}_{3}^{-}$, and the season (Wall et al. 2005; Pina-Ochoa and Alvarez-Cobelas 2006; Dahnke et al. 2008). On the other hand, the microenvironmental conditions with respect to $\mathrm{NO}_{3}^{-}$ availability can, within certain limits, also be influenced or controlled by the animal itself. For example, the periodic ventilation of the burrow for the purpose of respiration and filter feeding flushes the burrow with $\mathrm{NO}_{3}^{-}$from the water column (Kristensen et al. 1991; Stief and De Beer 2006). This $\mathrm{NO}_{3}^{-}$diffuses into the sediment surrounding the burrow, where it is consumed by denitrifying bacteria, resulting in a potentially significant sink for $\mathrm{NO}_{3}^{-}$in the burrow (Nielsen et al. 2004). However, it is unclear whether the bacteria in the animal gut must compete against this sink, or whether the ventilation of the burrow by the animal is efficient enough to maintain sufficiently high $\mathrm{NO}_{3}^{-}$concentrations in the burrow and the observed rate of $\mathrm{N}_{2} \mathrm{O}$ emission from the animals.

Temperature is another key environmental factor that probably influences the rate of $\mathrm{N}_{2} \mathrm{O}$ emission from aquatic invertebrates. The most obvious is the direct control of the metabolic rate of denitrifying bacteria in the animal gut. Additionally, the seasonal change in temperature affects the rate of $\mathrm{NO}_{3}^{-}$consumption by denitrifying bacteria in the sediment and, together with light, also that of pelagic and benthic primary producers (Jørgensen and Sørensen 1985; Pina-Ochoa and Alvarez-Cobelas 2006). The seasonal and diel change in temperature also affects the rates of 
respiration, feeding, and burrow ventilation of sedimentdwelling invertebrates (Leuchs 1986; Hymel and Plante 2000; Wang et al. 2001). Hence, temperature is expected to exert also an indirect control on the rate of $\mathrm{N}_{2} \mathrm{O}$ emission from aquatic invertebrates, namely via control of $\mathrm{NO}_{3}^{-}$ availability in the water column, inside the burrow, and inside the animal gut.

We investigated the effect of $\mathrm{NO}_{3}^{-}$availability and temperature on the $\mathrm{N}_{2} \mathrm{O}$ emission from the larvae of Chironomus plumosus (Insecta, Diptera), a widely distributed freshwater midge that lives in burrows reaching deep into the sediment. The larvae were either freshly collected from lake sediments or incubated in laboratory microcosms at specific $\mathrm{NO}_{3}^{-}$concentrations and temperatures. Our hypothesis was that $\mathrm{N}_{2} \mathrm{O}$ emission from $C$. plumosus larvae is controlled by temperature and $\mathrm{NO}_{3}^{-}$availability in the water column. We expected that these macroenvironmental conditions determine the microenvironmental conditions for the gut bacteria of C. plumosus larvae that produce $\mathrm{N}_{2} \mathrm{O}$ via incomplete denitrification. To investigate the nature of this coupling, we carried out numerical simulations of the $\mathrm{O}_{2}$ and $\mathrm{NO}_{3}^{-}$dynamics inside and around the burrow of the larva as a function of its ventilation activity.

\section{Methods}

Origin of materials - C. plumosus larvae were collected from sediments in two shallow lakes in the temperate zone. Lake Engelsholm, located in Jutland (Denmark), has a mean depth of $2.6 \mathrm{~m}$ and exhibits pronounced annual fluctuations of temperature $\left(4-20^{\circ} \mathrm{C}\right)$ and $\mathrm{NO}_{3}^{-}$concentrations $\left(0-150 \mu \mathrm{mol} \mathrm{L}^{-1}\right)$. Lake Großer Binnensee, located in Schleswig-Holstein (Germany), has a mean depth of $1.9 \mathrm{~m}$ and also exhibits pronounced annual fluctuations of temperature $\left(5-21^{\circ} \mathrm{C}\right.$; Deines et al. 2007) and $\mathrm{NO}_{3}^{-}$ concentrations $\left(0-130 \mu \mathrm{mol} \mathrm{L}^{-1}\right.$; Sommer 1989). In Lake Engelsholm, fourth-instar larvae were sieved from sediment collected with an Ekman grab and then used immediately for $\mathrm{N}_{2} \mathrm{O}$ measurements under in situ conditions. In Lake Großer Binnensee, fourth-instar larvae were collected on several occasions and kept at $15^{\circ} \mathrm{C}$ and in the dark until used in laboratory experiments within 2 weeks. Also, the sediment for these laboratory experiments was collected in Großer Binnensee and stored at $4^{\circ} \mathrm{C}$ in the dark until used within 2 months. Water samples for $\mathrm{NO}_{3}^{-}+\mathrm{NO}_{2}^{-}$analysis were taken in Lake Engelsholm and analyzed by the Environmental Center Ribe (Denmark). For this purpose, water samples taken at $1 \times$ and $2 \times$ Secchi depths were combined. During the time of this study, the Secchi depth varied between 1.05 and $3 \mathrm{~m}$.

Field investigation-C. plumosus larvae and lake water from Lake Engelsholm were sampled monthly from October 2006 to October 2007. Directly on the shore, 10 larvae were gently washed in sterile-filtered lake water $(0.20 \mu \mathrm{m}$, Sartorius) and individually placed in 3-mL blood collection vials (Terumo). The vials were completely filled with sterile-filtered lake water, sealed gas-tight with a butyl stopper, and incubated at in situ temperature. Subsamples of $1 \mathrm{~mL}$ were transferred in 1.5-h time intervals from each vial to a new, $\mathrm{N}_{2}$-flushed vial in which the biological activity was inhibited by $50 \mu \mathrm{L}$ of a saturated $\mathrm{ZnCl}_{2}$ solution. After each sampling, the vials were immediately pressure-equalized by inserting a hypodermic needle through the stopper for $<3 \mathrm{~s}$. In the laboratory, the $\mathrm{N}_{2} \mathrm{O}$ concentration in the vials containing the $1-\mathrm{mL}$ subsamples was measured by injecting $0.3 \mathrm{~mL}$ of headspace into a gas chromatograph with a ${ }^{63} \mathrm{Ni}$ electron capture detector (Shimadzu GC-8A). Calibration standards of $0-25 \mathrm{ppm}$ $\mathrm{N}_{2} \mathrm{O}$ in $\mathrm{N}_{2}$ were prepared by adding known amounts of $\mathrm{N}_{2} \mathrm{O}$ to $\mathrm{N}_{2}$-flushed septum vials of known volume. The detection limit of the gas chromatograph was 0.3 ppm $\mathrm{N}_{2} \mathrm{O}$ and the analytical precision of the measurements was $0.1 \mathrm{ppm}$. The linear increase of $\mathrm{N}_{2} \mathrm{O}$ concentration during the 3-h incubations was used to calculate the rate of $\mathrm{N}_{2} \mathrm{O}$ emission per specimen. The rate obtained by this approach corresponds to a potential rate, because the larvae were incubated in lake water and thereby may have been exposed to higher $\mathrm{NO}_{3}^{-}$concentrations than in their burrows. For each sampling date, the temperature and the concentrations of $\mathrm{NO}_{3}^{-}$and $\mathrm{N}_{2} \mathrm{O}$ in the lake water were also measured.

Laboratory experiments-Twelve $600-\mathrm{mL}$ glass beakers were filled with $500 \mathrm{~mL}$ lake sediment, $100 \mathrm{~mL}$ tap water, and 10-15 C. plumosus larvae. Within $2 \mathrm{~d}$, the larvae established steady, 10-cm-deep burrows in the sediment. The beakers were submersed in 12-liter aquaria filled with 10 liters aerated tap water. Tap water was used because of its low $\mathrm{NO}_{3}^{-}$concentration $\left(10 \mu \mathrm{mol} \mathrm{L}{ }^{-1}\right)$, which made it suitable for $\mathrm{NO}_{3}^{-}$addition experiments. Four aquaria each were incubated at $4^{\circ} \mathrm{C}, 15^{\circ} \mathrm{C}$, and $21^{\circ} \mathrm{C}$. For each temperature, the $\mathrm{NO}_{3}^{-}$concentration of the tap water was adjusted to $10,50,250$, and $500 \mu \mathrm{mol} \mathrm{L}^{-1}$ using a $1 \mathrm{~mol} \mathrm{~L}^{-1} \mathrm{NaNO}_{3}$ stock solution. This set of treatments covered a wide range of environmental conditions that $C$. plumosus larvae typically encounter in both their lake and stream habitats. In this experimental setup, C. plumosus larvae were studied with respect to $\mathrm{N}_{2} \mathrm{O}$ emission, $\mathrm{NO}_{3}^{-}$ concentration in hemolymph and gut, and ventilation parameters. Additionally, the setup served to study lake sediment with respect to $\mathrm{O}_{2}$ and $\mathrm{NO}_{3}^{-}$turnover rates.

$\mathrm{N}_{2} \mathrm{O}$ emission rates of individual larvae were measured in 3-mL gas-tight vials that contained the larva, $100 \mu \mathrm{L}$ of sterile-filtered water from the respective aquarium to keep the vial moist, and air as headspace (Stief et al. 2009). The larvae were moving around in the incubation vial without being directly exposed to the $\mathrm{NO}_{3}^{-}$in the minute volume of aquarium water. The sealed vials were incubated at the respective temperatures, and 3 or 4 headspace samples $(0.8 \mathrm{~mL})$ were withdrawn with a gas-tight syringe at time intervals of $1 \mathrm{~h}$ for $\mathrm{N}_{2} \mathrm{O}$ analysis by gas chromatography. Each headspace sample withdrawn was immediately replaced with air, which represented a dilution of the headspace that was corrected for. The linear increase of $\mathrm{N}_{2} \mathrm{O}$ concentration during the incubation was used to calculate the rate of $\mathrm{N}_{2} \mathrm{O}$ emission per specimen. The rate obtained by this approach corresponds to an actual rate, because the production of $\mathrm{N}_{2} \mathrm{O}$ in the animal gut was fueled 
exclusively by $\mathrm{NO}_{3}^{-}$that the animals had taken up while still being in their burrows.

$\mathrm{NO}_{3}^{-}$concentrations in the hemolymph and the gut contents were determined in freshly killed C. plumosus. Larvae were decapitated with a scalpel and the gut quickly pulled out with forceps. The gut contents enclosed by the peritrophic membrane were pulled out of the gut epithelium and collected in $100 \mu \mathrm{L}$ deionized water in a centrifuge tube placed on ice. The tubes were vigorously shaken to disperse the gut contents and centrifuged at $12,100 \times g$ and $4^{\circ} \mathrm{C}$, and the supernatant was collected in a fresh tube that was stored at $-20^{\circ} \mathrm{C}$. In the meantime, $5 \mu \mathrm{L}$ of hemolymph leaking out of the decapitated larva was collected in $50 \mu \mathrm{L}$ deionized water in a centrifuge tube and stored at $-20^{\circ} \mathrm{C}$. $\mathrm{NO}_{3}^{-}$concentrations were measured with the $\mathrm{VCl}_{3}$ reduction method (Braman and Hendrix 1989) combined with NO analysis on a chemiluminescence detector (CLD 86, EcoPhysics). Five microliters of sample was injected into the reaction chamber operated at $85^{\circ} \mathrm{C}$ for conversion of $\mathrm{NO}_{3}^{-}$and $\mathrm{NO}_{2}^{-}$to $\mathrm{NO}$. $\mathrm{NO}_{2}^{-}$concentrations were

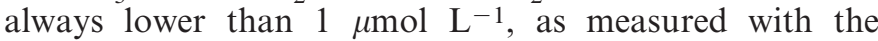
reaction chamber operated at $21^{\circ} \mathrm{C}$. For the calculation of in vivo concentrations of $\mathrm{NO}_{3}^{-}$, the dilution with deionized water as well as the water contents of the filled gut (85\%) was considered.

Ventilation activity of the $C$. plumosus larvae in sediment cores was determined by the $\mathrm{O}_{2}$ imaging method described previously (Polerecky et al. 2006). A square core $(\sim 15 \times$ $15 \times 25 \mathrm{~cm})$ containing a transparent polycarbonate window equipped with a planar $\mathrm{O}_{2}$ optode $(\sim 7 \times 15 \mathrm{~cm}$, $20 \mu \mathrm{m}$ thick) was filled with lake sediment and tap water, which was continuously flushed with air. A thin plastic barrier was inserted $\sim 2 \mathrm{~cm}$ from the optode, and the core was incubated for several days at $15^{\circ} \mathrm{C}$ to equilibrate. Afterwards, 10-15 C. plumosus larvae were placed in the volume confined by the barrier and the window. Within 2 $3 \mathrm{~d}$, larvae created steady burrows, few of which were close to the planar optode. $\mathrm{O}_{2}$ images in the sediment around these burrows were recorded in 15-s intervals while the cores were progressively incubated for $2 \mathrm{~d}$ at experimental temperatures $15^{\circ} \mathrm{C}, 4^{\circ} \mathrm{C}, 15^{\circ} \mathrm{C}, 21^{\circ} \mathrm{C}, 4^{\circ} \mathrm{C}$, and $21^{\circ} \mathrm{C}$. Durations of the pumping events $\left(\mathrm{t}_{\mathrm{PE}}\right)$ and resting periods $\left(t_{R P}\right)$, defined as the time intervals during which the measured $\mathrm{O}_{2}$ around the burrow increased and decreased, respectively (Polerecky et al. 2006), were first averaged for each individual burrow and then averaged over all observed burrows at each experimental temperature. The values of $t_{P E}$ and $t_{R P}$ determined during the transition periods $(3-5 \mathrm{~h})$ from one temperature to the next were disregarded.

Velocity of the water flow inside the burrow during the pumping events (PEs) was determined by a fluorescence imaging method. Sediments with $C$. plumosus larvae were incubated for at least $5 \mathrm{~d}$ in glass beakers at experimental temperatures $4^{\circ} \mathrm{C}, 15^{\circ} \mathrm{C}$, and $21^{\circ} \mathrm{C}$. After an equilibrium was established, a fluorescent dye $\left(10 \mathrm{mg} \mathrm{L}^{-1}\right.$ fluorescein) was gently injected above the burrow neighboring the glass wall and the fluorescence intensity was imaged in 1-s intervals using pulsed $(\sim 40 \mathrm{~ms})$ illumination with a blue light-emitting diode ( $\lambda_{\max }=455 \mathrm{~nm}$, Lumileds). Velocity of the water flow was calculated from the spatial progression of the dye front along the burrow in time, as determined by processing of 5-10 images recorded subsequently during the PE. The dye was injected above the burrow for each replicate measurement. The average velocities for each experimental temperature were calculated from the mean values determined for each individual burrow.

$\mathrm{O}_{2}$ and $\mathrm{NO}_{3}^{-}$consumption rates in the sediment were obtained by microsensor profiling and modeling (see below). Microsensors for $\mathrm{O}_{2}$ and $\mathrm{NO}_{3}^{-}$(Revsbech 1989; Sweerts and De Beer 1989) were simultaneously used in a measuring setup as described previously (Stief and De Beer 2002). At least three vertical steady-state concentration profiles per sediment beaker were recorded from $2 \mathrm{~mm}$ above to $10 \mathrm{~mm}$ below the sediment surface.

Numerical simulations - A diffusion-reaction model was developed and implemented in Matlab (version 7, MathWorks) to simulate the coupled $\mathrm{O}_{2}$ and $\mathrm{NO}_{3}^{-}$dynamics inside and around a cylindrical burrow induced by ventilation activity of the larva. The aim was to estimate the effects of a given sequence of pumping and resting intervals and of the sedimentary uptake of $\mathrm{O}_{2}$ and $\mathrm{NO}_{3}^{-}$on the magnitude of $\mathrm{O}_{2}$ and $\mathrm{NO}_{3}^{-}$fluctuations inside the burrow lumen.

Modeling was done in a cylindrical system of coordinates (axial dimension $[z]$, radial distance $[r]$, axial angle $[\varphi]$ ), employing a regular grid in the $r$ and $z$ directions (grid step $\delta r$ and $\delta z$ ) and a uniform time step $(\delta t)$. The burrow was approximated by a cylinder of radius $r_{0}$, starting at position $z=0$, which corresponded to the sediment surface, and extending in the positive $z$ direction, i.e., into the sediment, towards infinity. Because of the assumed cylindrical symmetry, concentrations of $\mathrm{O}_{2}$ and $\mathrm{NO}_{3}^{-}$, denoted as $c$ and $e$, respectively, were considered only functions of $z, r$, and time $(t)$, i.e., were independent of $\varphi$.

During the resting period (RP), we assumed that the water inside the burrow lumen was stagnant and thus the solute transport in and around the burrow was governed by diffusion. Consequently, the dynamics of $c$ and $e$ followed the diffusion-reaction equations

$$
\begin{gathered}
\frac{\partial c}{\partial t}=D_{c} \Delta c-R_{c}(c) \\
\frac{\partial e}{\partial t}=D_{e} \Delta e-R_{e}(e, c)
\end{gathered}
$$

Here, the Laplacian operator expressed in cylindrical coordinates takes the form $\Delta=(1 / r) \partial / \partial r+\partial^{2} / \partial r^{2}+\partial^{2} / \partial z^{2}$ (the derivative with respect to $\varphi$ was zero because of axial symmetry). The diffusion coefficients of $\mathrm{O}_{2}\left(D_{c}\right)$ and $\mathrm{NO}_{3}^{-}$ $\left(D_{e}\right)$ were assumed to be constant throughout the calculation domain, which was reasonable because of the very high water content of the sediment (85\%). The values of $R_{c}$ and $R_{e}$ inside the burrow ( $r \leq r_{0}$, for all positive $z$ ) and in the overlying water were set to zero. In the sediment surrounding the burrow, the volume-specific $\mathrm{O}_{2}$ (OCR) and $\mathrm{NO}_{3}^{-}$(NCR) consumption rates were assumed to follow the Michaelis-Menten law with respect to the corresponding substrates, with NCR being additionally 
inhibited by $\mathrm{O}_{2}$ in a reversible and noncompetitive manner (Bergethon 1998). Thus, OCR and NCR were expressed as (Soetaert et al. 1996; Brand et al. 2009)

$$
\begin{gathered}
R_{c}(c)=O C R_{\max } \frac{c}{c+K_{m}^{O_{2}}} \\
R_{e}(e, c)=N C R_{\max } \frac{e}{e+K_{m}^{N O_{3}^{-}}}\left(1-\frac{c}{c+K_{i}^{O_{2}}}\right)
\end{gathered}
$$

where $K_{m}$ and $K_{i}$ denote the affinity constants towards the substrate and the inhibitor, respectively. The maximum rates as well as the affinity constants used in these expressions were estimated by fitting the steady-state microsensor profiles measured at the sediment surface with this model (results summarized in Table 1).

During the pumping interval, $c$ and $e$ in the sediment surrounding the burrow $\left(r>r_{0}\right)$ were assumed to follow the same diffusion-reaction model (Eqs. 1, 2). Pumping of water was realized by moving the water volume inside the burrow downward by a $z$ step of $z_{s}=v \delta t$, where $\delta t$ was the time step of the numerical calculation and $v$ was the flow velocity. Technically, this was done by setting the concentration profiles at time $t+\delta t$ and at positions $z+$ $z_{s}$ to those at time $(t)$ and at positions $(z)$, i.e., $c\left(r, z+z_{s}, t+\right.$ $\delta t)=c(r, z, t)$ and $e\left(r, z+z_{s}, t+\delta t\right)=e(r, z, t)$, for all $r \leq r_{0}$ before numerically applying the time step governed by Eqs. $1,2$.

With respect to boundary conditions, the concentrations at the sediment-water interface, i.e., at $z=0$ and for all $r$, were fixed to the corresponding values in the overlying water $\left(c_{\mathrm{w}}\right.$ and $e_{\mathrm{w}}$; Table 1) during both pumping and resting intervals. A zero-flux boundary condition was applied at the boundaries of the radial coordinate, i.e., at $r=r_{\max }$. Furthermore, $r_{\max }$ was set sufficiently large to ensure that $c$ and $e$ remained zero at all times and at all depths greater than the $\mathrm{O}_{2}$ and $\mathrm{NO}_{3}^{-}$penetration depths calculated close to the sediment-water interface. The flux at the bottom of the calculation domain, i.e., at $z=z_{\max }$, was set equal to that at $z_{\max }-\Delta z$. Because $\Delta z \ll z_{\max }$, this approximation had no effect on the calculated dynamics.

Two additional assumptions were considered in the model. First, the larval respiration as well as possible direct effects of the larva on $\mathrm{NO}_{3}^{-}$turnover inside the burrow were neglected, because the model aimed at estimating the influence of the surrounding sediment on $\mathrm{O}_{2}$ and $\mathrm{NO}_{3}^{-}$ dynamics in the burrow lumen. Second, the diffusive boundary layer (DBL) next to the burrow wall during the pumping interval was assumed to have zero thickness. Fluxes of solutes across the sediment-water interface have been shown to decrease with an increasing DBL thickness. However, for a DBL thickness of $0.5 \mathrm{~mm}$, which is a reasonable maximum in the case of a burrow with a diameter of $1.5 \mathrm{~mm}, \mathrm{O}_{2}$ and $\mathrm{NO}_{3}^{-}$fluxes decrease, respectively, by less than $\sim 15 \%$ and $1-2 \%$ compared to the fluxes at zero DBL (Brand et al. 2009). Thus, the simplifying assumption of a zero DBL thickness does not affect the conclusions of this study.

Numerical simulations were performed using parameters summarized in Table 1, which were either determined

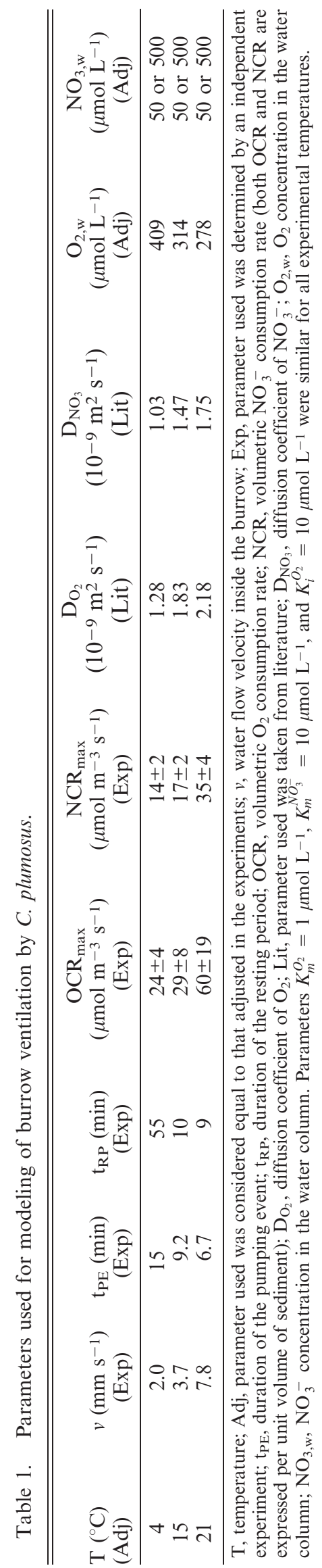




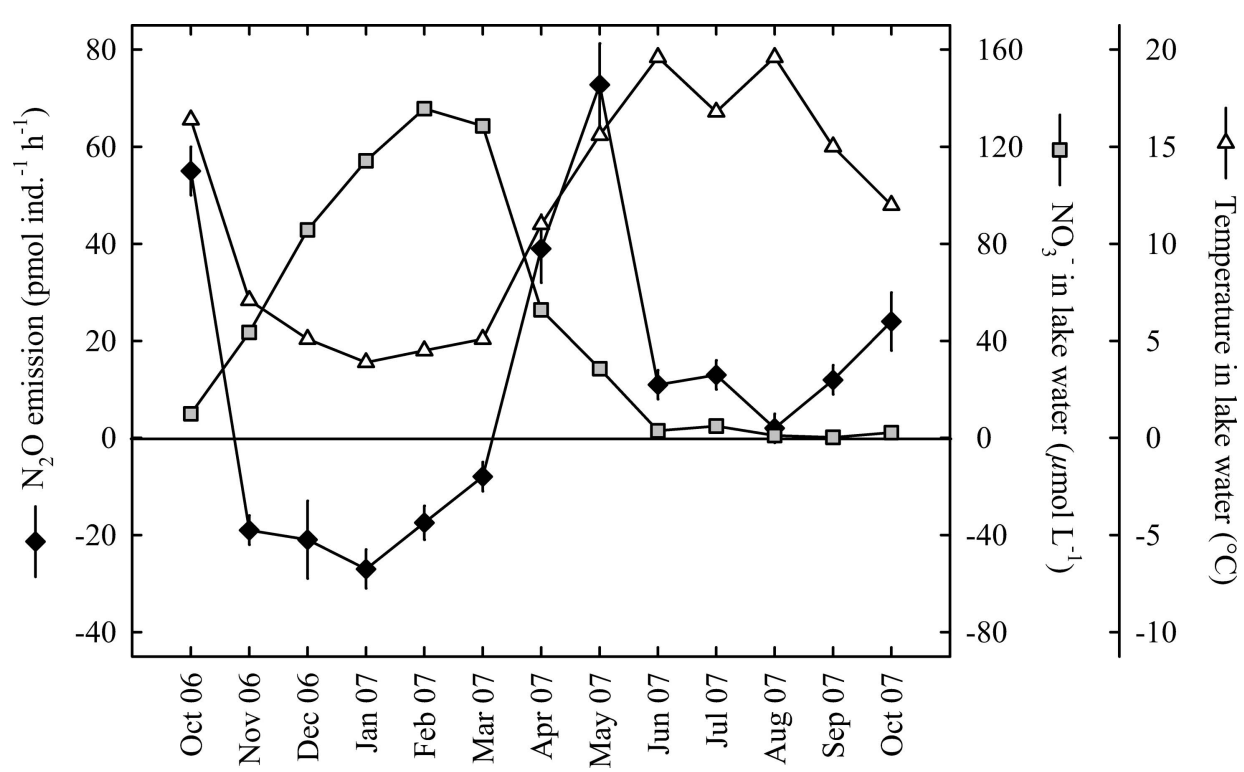

Fig. 1. Annual variation of temperature and $\mathrm{NO}_{3}^{-}$concentration in Lake Engelsholm (Denmark, Jutland) and of the potential rate of $\mathrm{N}_{2} \mathrm{O}$ emission from C. plumosus larvae. The potential rate of $\mathrm{N}_{2} \mathrm{O}$ emission was determined with larvae that were freshly collected and separated from the lake sediment and incubated in lake water at in situ temperature. Means $\pm \mathrm{SE}$ of $n=10$ replicates are shown.

experimentally (volume-specific consumption rates, pumping and resting intervals, flow velocities, burrow radius), adjusted during experiments $\left(\mathrm{NO}_{3}^{-}\right.$concentrations in the water column), or taken from the literature (temperaturecorrected diffusion coefficients; Broecker and Peng 1974; Li and Gregory 1974). Initially, $c$ and $e$ were set to zero everywhere in the sediment $(z>0)$ and equal to the overlying water concentrations at $z=0$. Subsequently, $\mathrm{O}_{2}$ and $\mathrm{NO}_{3}^{-}$concentrations as a function of time were calculated during the succession of three PEs, each followed by an RP. The durations of the first two pumping and resting intervals were set to $t_{P E}$ and $t_{R P}$ (Table 1), respectively, to evaluate the dynamics under average conditions determined experimentally. To quantify the effect of a much shorter pumping and much longer resting interval, the durations of the third pumping and resting intervals were set to $t_{\mathrm{PE}} / 2$ and $2 t_{\mathrm{RP}}$, respectively. To obtain scalar quantities that reflect the temporal variations of $\mathrm{O}_{2}$ and $\mathrm{NO}_{3}^{-}$concentrations inside and around the burrow at selected depths $(10$ and $50 \mathrm{~cm})$, the radial distributions of $c$ and $e$ at these depths were averaged over intervals $r \in\left\langle 0, r_{0}\right\rangle$ and $r \in\left\langle r_{0}, 2 r_{0}\right\rangle$, respectively.

\section{Results}

Nitrous oxide emission from C. plumosus-Field investigation: In Lake Engelsholm, the $\mathrm{NO}_{3}^{-}$concentration in the water column showed a pronounced seasonal variation, with high values during winter and low values during summer, whereas the temperature curve showed the opposite trend (Fig. 1). The potential rate of $\mathrm{N}_{2} \mathrm{O}$ emission from C. plumosus larvae collected in Lake Engelsholm followed the temperature curve to some degree, but very high emission rates were observed in April and May 2007. In the warm season, the potential rate of $\mathrm{N}_{2} \mathrm{O}$ emission ranged between 2 and 73 pmol ind. ${ }^{-1} \mathrm{~h}^{-1}$. In winter, however, uptake of $\mathrm{N}_{2} \mathrm{O}$ by the larvae of up to $-27 \mathrm{pmol}$ ind. ${ }^{-1} \mathrm{~h}^{-1}$ was observed. This means that the $\mathrm{N}_{2} \mathrm{O}$ concentration of the lake water decreased during the incubation, which was not the case in control vials without larvae. Because $\mathrm{N}_{2} \mathrm{O}$ concentrations in the lake water during these measurements ranged between 32 and $80 \mathrm{nmol} \mathrm{L}^{-1}$ (annual average $48 \pm 14 \mathrm{nmol} \mathrm{L}^{-1}$ ), the amount of $\mathrm{N}_{2} \mathrm{O}$ available in the measuring vial was not limiting the larval $\mathrm{N}_{2} \mathrm{O}$ consumption.

At $\mathrm{NO}_{3}^{-}$concentrations above $25 \mu \mathrm{mol} \mathrm{L} \mathrm{L}^{-1}$, the potential rate of $\mathrm{N}_{2} \mathrm{O}$ emission was significantly positively correlated with temperature (Spearman's $R=0.775, p=$ 0.041 ), but this correlation also considered negative $\mathrm{N}_{2} \mathrm{O}$ emission rates. At temperatures higher than $10^{\circ} \mathrm{C}$, the potential rate of $\mathrm{N}_{2} \mathrm{O}$ emission was significantly positively correlated with $\mathrm{NO}_{3}^{-}$concentration (Spearman's $R=$ $0.593, p=0.049)$.

Laboratory investigation: The average rates of $\mathrm{N}_{2} \mathrm{O}$ emission from $C$. plumosus collected from laboratory microcosms ranged from 14 to 122 pmol ind. ${ }^{-1} \mathrm{~h}^{-1}$ and varied with both the $\mathrm{NO}_{3}^{-}$concentration in the water column and the incubation temperature (Fig. 2). The emission rates increased significantly with $\mathrm{NO}_{3}^{-}$concentration at $15^{\circ} \mathrm{C}$ and $21^{\circ} \mathrm{C}$, but not at $4^{\circ} \mathrm{C}$ (Table 2). Furthermore, the rates increased with temperature at $\mathrm{NO}_{3}^{-}$ concentrations of 250 and $500 \mu \mathrm{mol} \mathrm{L}-1$, but not at 10 and $50 \mu \mathrm{mol} \mathrm{L}-1 \mathrm{NO}_{3}^{-}$. 


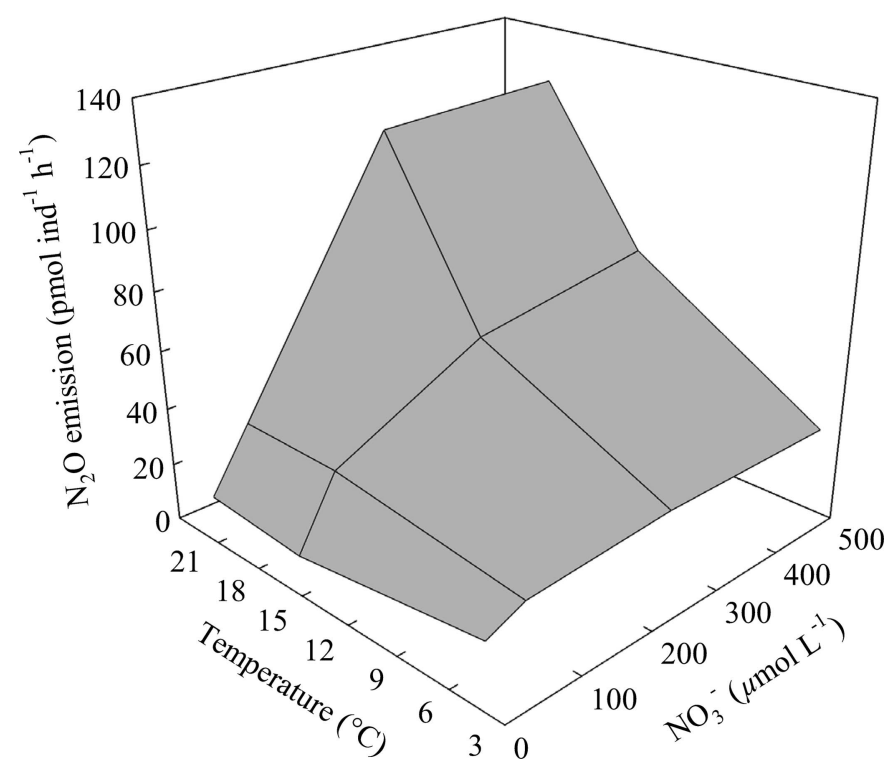

Fig. 2. Rates of $\mathrm{N}_{2} \mathrm{O}$ emission from C. plumosus larvae after they were incubated for $2-4 \mathrm{~d}$ in laboratory microcosms at different temperatures and $\mathrm{NO}_{3}^{-}$concentrations in the water column. Means of $n=6$ replicates are shown.

Nitrate concentration in gut and hemolymph of C. plumosus-Generally, the concentration of $\mathrm{NO}_{3}^{-}$in the gut and hemolymph of $C$. plumosus larvae increased with the $\mathrm{NO}_{3}^{-}$ concentration in the water column of the laboratory microcosms (Fig. 3). In all treatments, the average $\mathrm{NO}_{3}^{-}$ concentrations in the gut and hemolymph were as high as or even higher than in the water column. At $4^{\circ} \mathrm{C}$ and $15^{\circ} \mathrm{C}$, the $\mathrm{NO}_{3}^{-}$concentrations in the gut and hemolymph were in most cases not different from those in the water column ( $t$-test, $T \geq-2.133$, df $=11, p>0.05)$, whereas at $21^{\circ} \mathrm{C}$, they were in most cases significantly higher than in the water column ( $t$-test, $T<-2.449, \mathrm{df}=11, p<0.05)$, which must be caused by $\mathrm{NO}_{3}^{-}$production or accumulation in the larvae (see Discussion).

Ventilation activity of $\mathrm{C}$. plumosus and its consequencesBecause of the ventilation activity of a C. plumosus larva, $\mathrm{O}_{2}$ concentrations in and around the burrow exhibited characteristic dynamics consisting of alternating periods of increase and decrease (Fig. 4). Based on these dynamics, the larval activity was divided into pumping $\left(\mathrm{O}_{2}\right.$ increase $)$

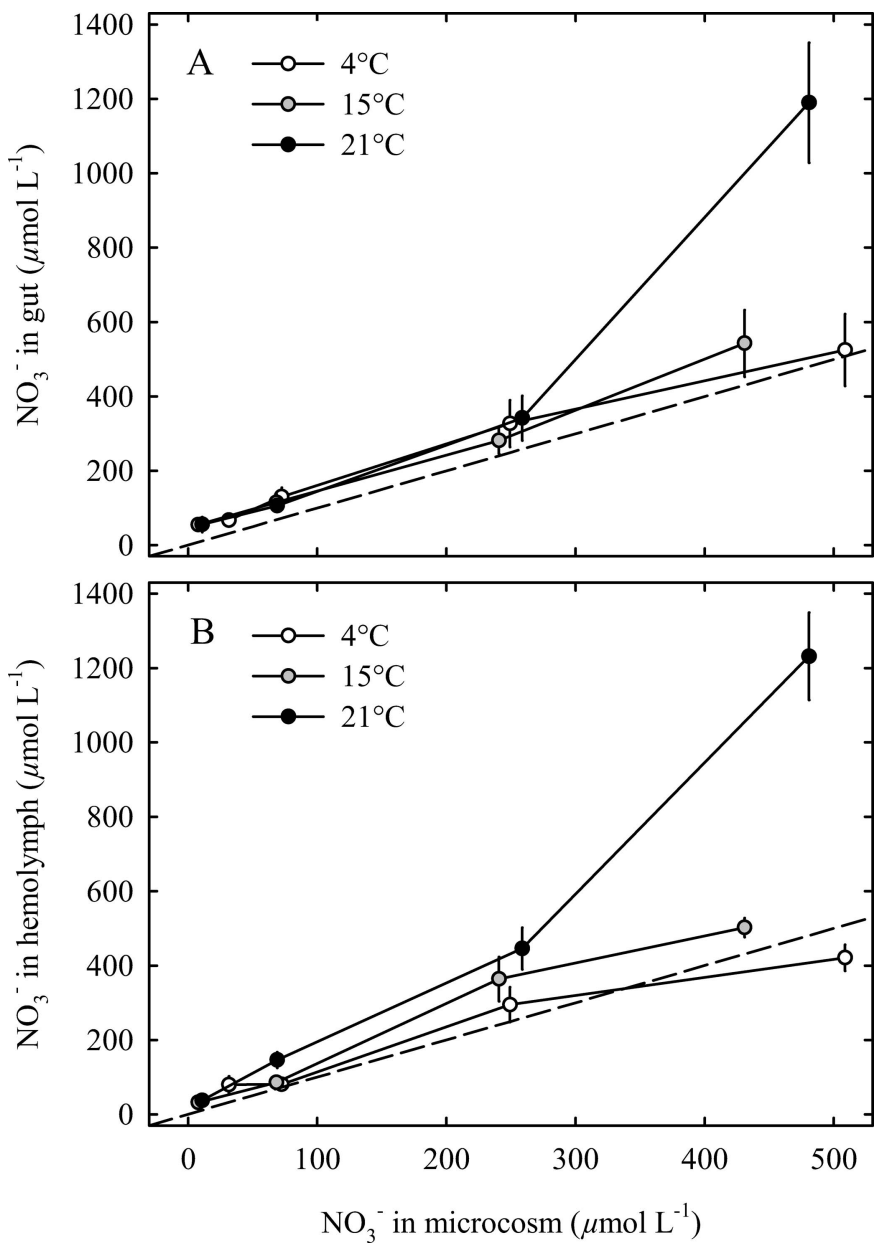

Fig. 3. $\mathrm{NO}_{3}^{-}$concentration in (A) the gut and (B) the hemolymph of $C$. plumosus larvae incubated in laboratory microcosms at different temperatures and $\mathrm{NO}_{3}^{-}$concentrations in the water column. The dotted line indicates identical concentrations in the water column and in the gut and hemolymph. Means $\pm \mathrm{SE}$ of $n=12$ replicates are shown.

and resting $\left(\mathrm{O}_{2}\right.$ decrease $)$ intervals of durations $t_{P E}$ and $t_{R P}$, respectively, as suggested by Polerecky et al. (2006). The analysis of the complete $\mathrm{O}_{2}$ time series, which lasted $4 \mathrm{~d}$ at each experimental temperature, revealed that $t_{\mathrm{PE}}$ and $\mathrm{t}_{\mathrm{RP}}$ varied considerably within the time series for each observed burrow as well as among the different burrows observed at each temperature (see symbols with their corresponding

Table 2. Correlations between larval $\mathrm{N}_{2} \mathrm{O}$ emission rate and $\mathrm{NO}_{3}^{-}$concentration in the water column (left columns) and between larval $\mathrm{N}_{2} \mathrm{O}$ emission rate and temperature (right columns).

\begin{tabular}{|c|c|c|c|c|c|}
\hline \multirow[b]{2}{*}{ Temperature } & \multicolumn{2}{|c|}{$\begin{array}{c}\mathrm{N}_{2} \mathrm{O} \text { emission rate vs. } \mathrm{NO}_{3}^{-} \\
\text {concentration }\end{array}$} & \multirow[b]{2}{*}{$\mathrm{NO}_{3}^{-}$concentration } & \multicolumn{2}{|c|}{$\mathrm{N}_{2} \mathrm{O}$ emission rate vs. temperature } \\
\hline & $R$ & $p$ & & $R$ & $p$ \\
\hline $4^{\circ} \mathrm{C}$ & -0.057 & 0.815 & $10 \mu \mathrm{mol} \mathrm{L}^{-1}$ & -0.401 & 0.196 \\
\hline $15^{\circ} \mathrm{C}$ & 0.612 & 0.010 & $50 \mu \mathrm{mol} \mathrm{L}-1$ & -0.055 & 0.858 \\
\hline \multirow[t]{2}{*}{$21^{\circ} \mathrm{C}$} & 0.542 & 0.014 & $250 \mu \mathrm{mol} \mathrm{L}^{-1}$ & 0.686 & 0.003 \\
\hline & & & $500 \mu \mathrm{mol} \mathrm{L}-1$ & 0.860 & $<0.001$ \\
\hline
\end{tabular}

$\mathrm{N}_{2} \mathrm{O}$ emission rate vs. $\mathrm{NO}_{3}^{-}$concentration: Pearson's correlation coefficient $R$ and the level of probability $p$ are given; $n=17-24 . \mathrm{N}_{2} \mathrm{O}$ emission rate vs. temperature: Spearman's correlation coefficient $R$ and the level of probability $p$ are given; $n=12-20$. 


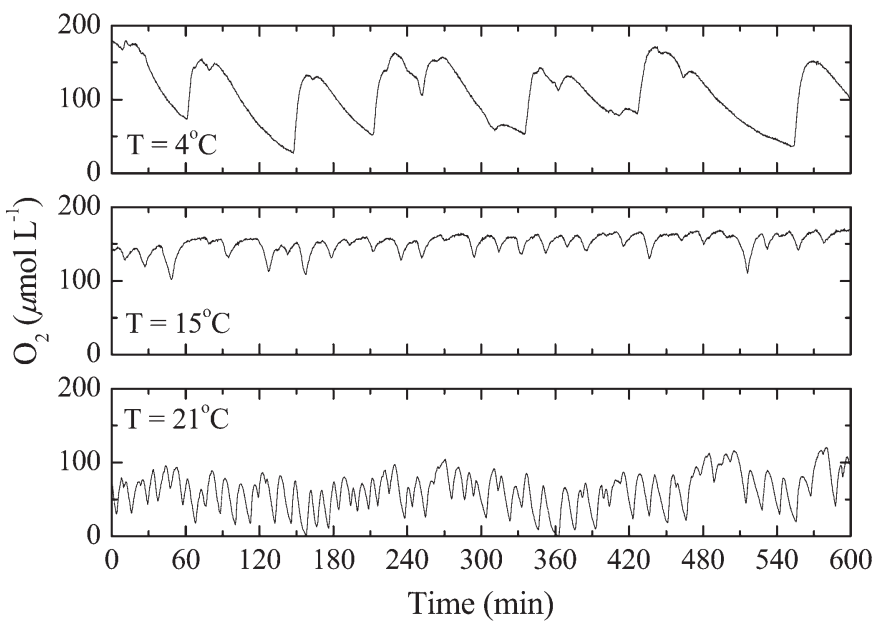

Fig. 4. Time series of the $\mathrm{O}_{2}$ concentration close to the burrow of a $C$. plumosus larva, as determined with the oxygen imaging method at three experimental temperatures. Typical examples of concentrations measured at depths $2-3 \mathrm{~cm}$ below the sediment surface are shown. Note that the absolute values of the measured $\mathrm{O}_{2}$ concentrations depend on the distance between the burrow and the planar optode, and thus do not reflect directly the $\mathrm{O}_{2}$ concentrations inside the burrow. Thus, data like these were used only to quantify temporal aspects of the burrow ventilation.

error bars in Fig. 5A,B). When considering different burrows separately, variability of $t_{\mathrm{PE}}$ was similar for all temperatures (between 2 and $9 \mathrm{~min}$ ), whereas variability of $t_{R P}$ enormously increased to $20-55 \mathrm{~min}$ at $4{ }^{\circ} \mathrm{C}$ compared to that at $15^{\circ} \mathrm{C}$ and $21^{\circ} \mathrm{C}(2-9 \mathrm{~min})$. When averaged over all observed burrows, $t_{\mathrm{PE}}$ decreased with temperature (Fig. 5A), whereas $t_{R P}$ enormously increased at $4^{\circ} \mathrm{C}$ compared to $t_{R P}$ at $15^{\circ} \mathrm{C}$ and $21^{\circ} \mathrm{C}$ (Fig. 5B). The fluorescent dye imaging experiment revealed a similarly high degree of variability of the flow velocity inside a ventilated burrow when comparing individual burrows at each experimental temperature (Fig. 5C). The average velocities, however, exhibited a clear increasing trend with temperature.

Numerical simulations of $\mathrm{O}_{2}$ and $\mathrm{NO}_{3}^{-}$dynamics inside and around a ventilated burrow revealed that the average $\mathrm{O}_{2}$ concentrations inside the burrow increased abruptly with time after the pumping started, and approached a steady-state value as the time passed (Fig. 6A-C). The delay of the abrupt increase in concentration, $\Delta \mathrm{t}$, was related to the distance from the burrow entry, $\mathrm{L}$, as $\Delta \mathrm{t}=$ $\mathrm{L} / v$. The $\mathrm{O}_{2}$ concentrations inside the burrow at the end of the average pumping interval decreased approximately linearly with $\mathrm{L}$ and, depending on temperature, reached 95 $98 \%$ and $70-85 \%$ of the water column concentration at $\mathrm{L}=$ 10 and $50 \mathrm{~cm}$, respectively (Fig. 7A, open symbols). After the pumping was stopped, the average $\mathrm{O}_{2}$ concentrations inside the burrow decreased in an approximately exponential manner with time (Fig. 6A-C), reaching $50-55 \%$ (at L $=10 \mathrm{~cm})$ and $\sim 40 \%($ at $\mathrm{L}=50 \mathrm{~cm})$ of the water column concentration at the end of the average $\mathrm{RP}$ at $15^{\circ} \mathrm{C}$ and $21^{\circ} \mathrm{C}$ (Fig. 7A, filled circles and squares, respectively). The decrease of the $\mathrm{O}_{2}$ concentrations with $\mathrm{L}$ at the end of the average $\mathrm{RP}$ at $4{ }^{\circ} \mathrm{C}$ was more pronounced, reaching $\sim 10 \%$
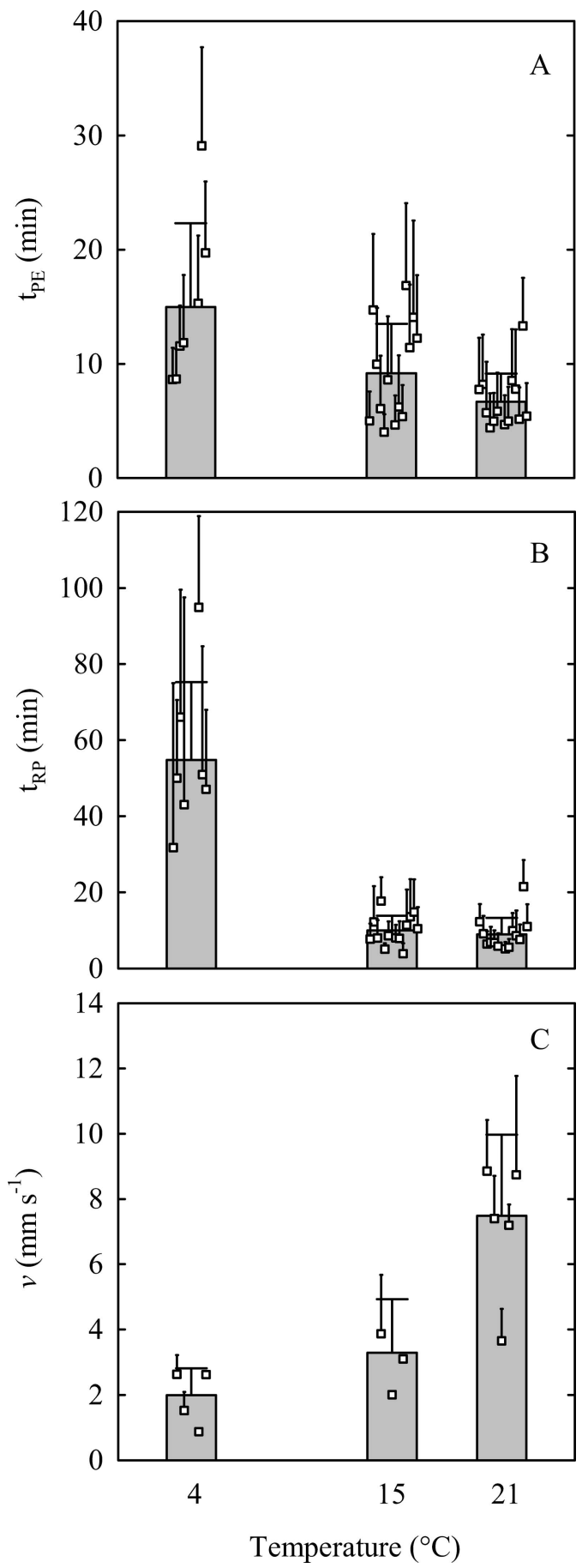

Fig. 5. Durations of (A) pumping events $\left(t_{\mathrm{PE}}\right)$, (B) resting periods $\left(t_{R P}\right)$, and $(C)$ flow velocities inside a ventilated burrow $(v)$, as a function of temperature. Squares with error bars represent average (AV) and standard deviation (SD) calculated for individual burrows from time series lasting for several hundreds $\left(t_{\mathrm{PE}}\right.$ and $\left.\mathrm{t}_{\mathrm{RP}}\right)$ and tens $(v)$ of minutes, and columns with error bars represent total $\mathrm{AV}$ and $\mathrm{SD}$ for each experimental temperature. Note different scaling of (A) and (B).

and $\sim 4 \%$ of the water column concentration at 10 and $50 \mathrm{~cm}$, respectively (Fig. 7A, filled triangles). Calculated $\mathrm{O}_{2}$ concentrations, when averaged over the sediment volume at radial distances between $r_{0}$ and $2 r_{0}$ ( $r_{0}$ is the burrow radius), 

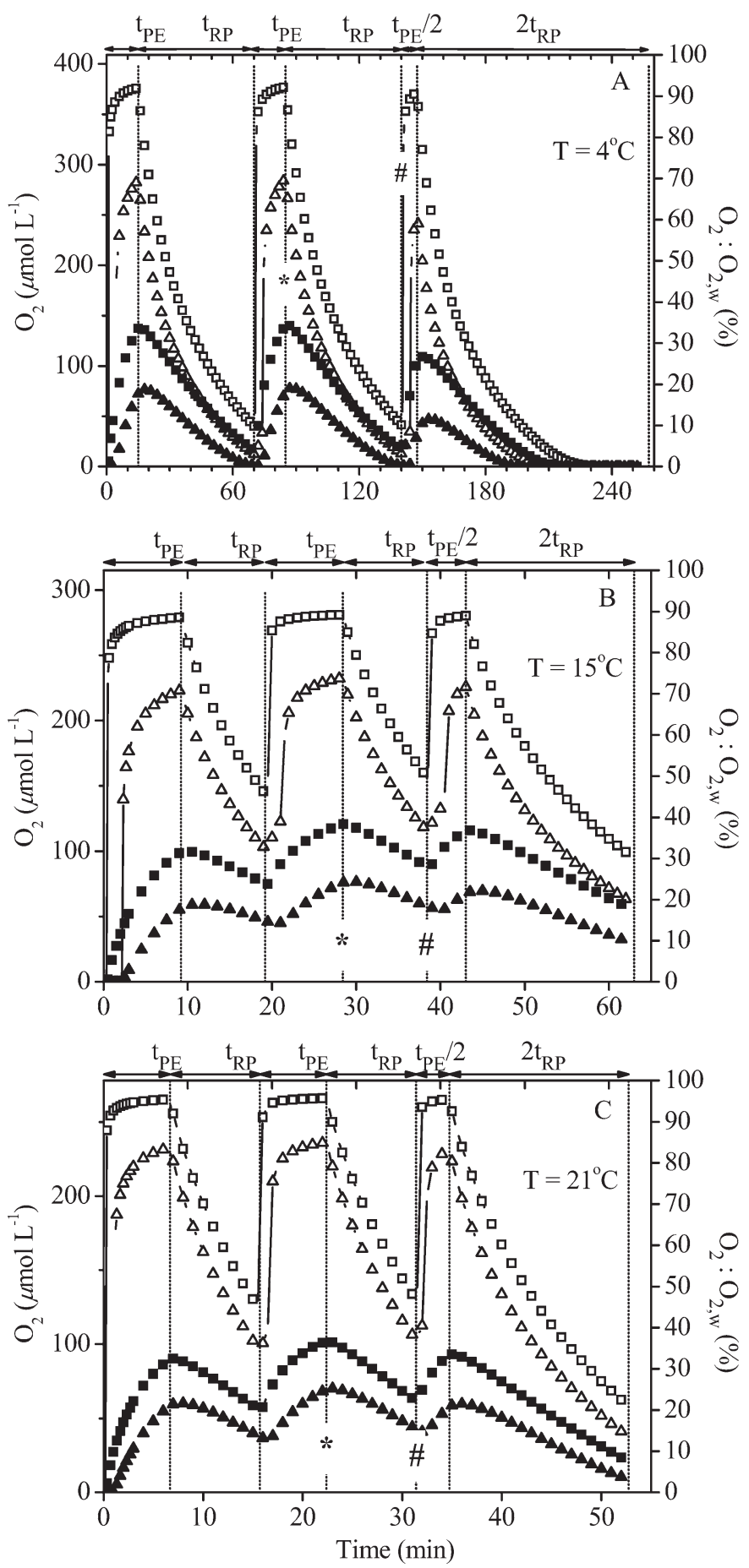

Fig. 6. (A-C) $\mathrm{O}_{2}$ concentrations inside (averaged from 0 to $r_{0}$; open symbols) and around (averaged from $r_{0}$ to $2 r_{0}$; filled symbols) a ventilated burrow as a function of time and temperature, modeled for 3 successive pumping and resting intervals. Squares and triangles represent the situations at distances of 10 and $50 \mathrm{~cm}$ from the burrow entry, respectively. Pumping and resting intervals used in the simulation are indicated by vertical dotted lines. *, end of an average pumping event; \#, end of an average resting period.
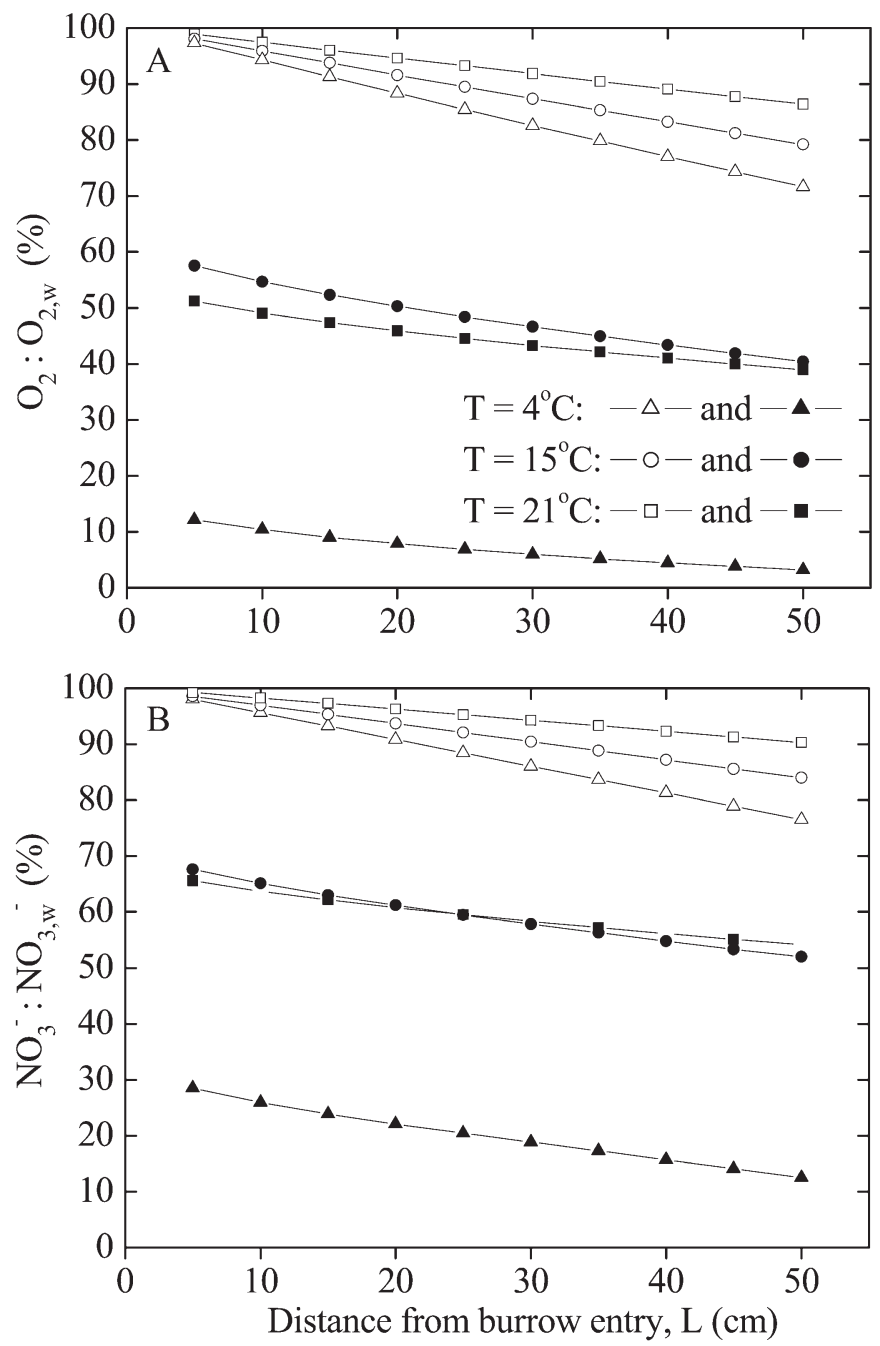

Fig. 7. (A) $\mathrm{O}_{2}$ and (B) $\mathrm{NO}_{3}^{-}$concentrations inside the burrow plotted as a function of the distance from the burrow entry at the end of an average pumping event (open symbols) and an average resting period (filled symbols). These time points are indicated in Fig. 6A-C and Fig. 8A-C by * and \#, respectively. Concentrations were normalized to the concentration in the water column.

exhibited similar fluctuating patterns to those directly measured next to the burrows by the planar optode (compare Figs. 4 and 6), confirming that the approximations made and parameters applied in the modeling were realistic for the experimental settings used.

The temporal patterns seen in the simulated $\mathrm{NO}_{3}^{-}$ concentrations were qualitatively similar to those for $\mathrm{O}_{2}$. Specifically, $\mathrm{NO}_{3}^{-}$concentrations, at a given distance from the burrow entry, increased abruptly after the pumping started and approached a steady state with increasing time (Fig. 8A-C). At the end of the average pumping interval, $\mathrm{NO}_{3}^{-}$concentrations inside the burrow decreased approximately linearly with L, and, depending on temperature, reached $95-98 \%$ and $75-90 \%$ of the water column concentration at $\mathrm{L}=10$ and $50 \mathrm{~cm}$, respectively (Fig. 7B, open symbols). After the pumping was stopped, the average 

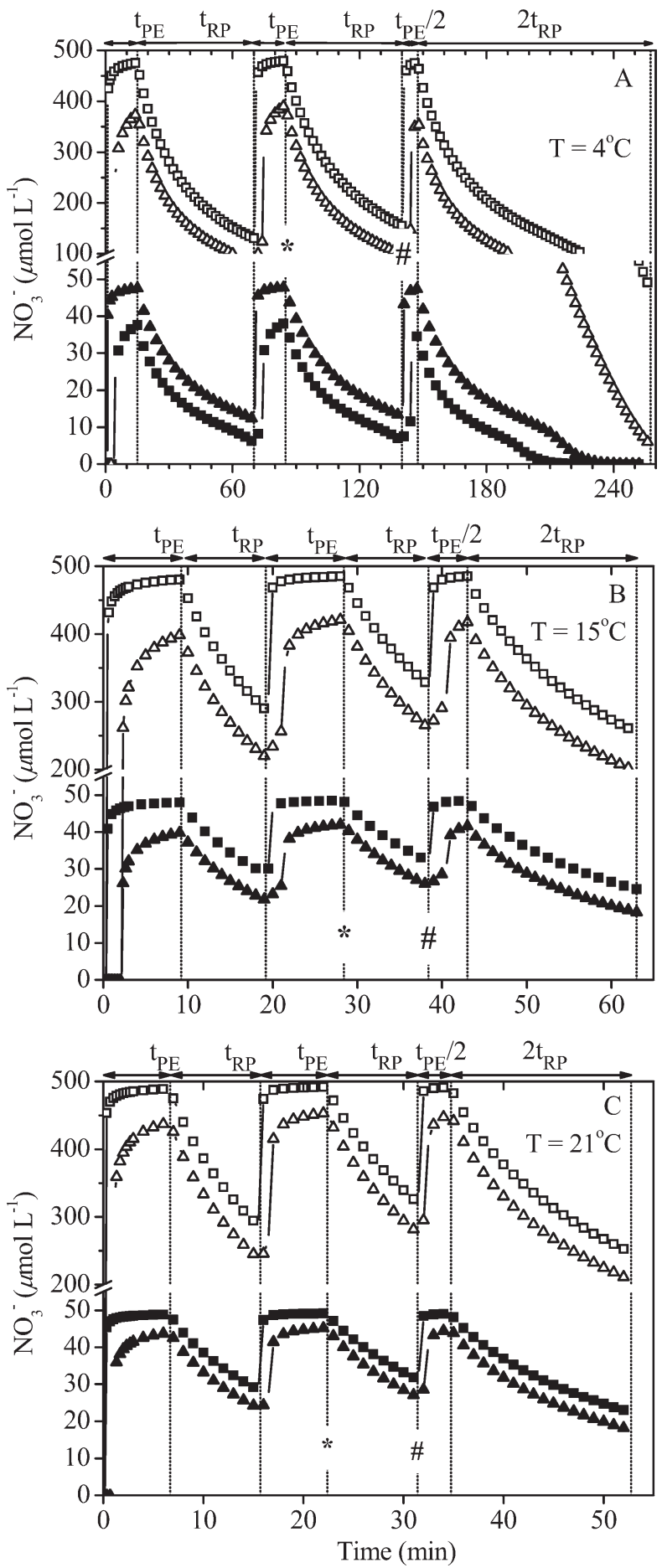

Fig. 8. (A-C) $\mathrm{NO}_{3}^{-}$concentrations inside (averaged from 0 to $r_{0}$ ) a ventilated burrow as a function of time and temperature, modeled for 3 successive pumping and resting intervals. Squares and triangles represent the situations at distances of 10 and $50 \mathrm{~cm}$ from the burrow entry, respectively; open and filled symbols correspond to the overlying water $\mathrm{NO}_{3}^{-}$concentrations 500 and $50 \mu \mathrm{mol} \mathrm{L}-1$, respectively. Pumping and resting intervals used in the simulation are indicated by vertical dotted lines. *, end of an average pumping event; \#, end of an average resting period.
$\mathrm{NO}_{3}^{-}$concentrations inside the burrow decreased in an approximately exponential manner with time (Fig. 8A-C), reaching $\sim 65 \%($ at $\mathrm{L}=10 \mathrm{~cm})$ and $\sim 55 \%($ at $\mathrm{L}=50 \mathrm{~cm})$ of the water column concentration at the end of the average RP at $15^{\circ} \mathrm{C}$ and $21^{\circ} \mathrm{C}$ (Fig. 7B, filled circles and squares, respectively). The decrease of the $\mathrm{NO}_{3}^{-}$concentrations with $\mathrm{L}$ at the end of the average $\mathrm{RP}$ at $4^{\circ} \mathrm{C}$ was more pronounced, reaching $\sim 28 \%$ and $\sim 12 \%$ of the water column concentration at $10 \mathrm{~cm}$ and $50 \mathrm{~cm}$, respectively (Fig. 7B, filled triangles). In general, the magnitude of the temporal variations of $\mathrm{NO}_{3}^{-}$concentration inside the burrow was lower than that of the $\mathrm{O}_{2}$ concentration. This was related to the fact that $\mathrm{NO}_{3}^{-}$had to diffuse beyond the layer with high $\mathrm{O}_{2}$ concentrations before it could be consumed at appreciable rates, leading to a delay in $\mathrm{NO}_{3}^{-}$consumption relative to $\mathrm{O}_{2}$ consumption. The simulated $\mathrm{NO}_{3}^{-}$dynamics, when normalized to the $\mathrm{NO}_{3}^{-}$concentrations in the water column, $\mathrm{NO}_{3, \mathrm{w}}$, were practically identical for $\mathrm{NO}_{3, \mathrm{w}}=50$ and $500 \mu \mathrm{mol} \mathrm{L}^{-1}$ (data not shown).

\section{Discussion}

$\mathrm{N}_{2} \mathrm{O}$ emission rate vs. $\mathrm{NO}_{3}^{-}$availability and temperature - The rate of $\mathrm{N}_{2} \mathrm{O}$ emission from C. plumosus larvae kept in laboratory microcosms increased with the $\mathrm{NO}_{3}^{-}$ concentration in the water column at $15^{\circ} \mathrm{C}$ and $21^{\circ} \mathrm{C}$, but not at $4^{\circ} \mathrm{C}$. Similarly, the potential rate of $\mathrm{N}_{2} \mathrm{O}$ emission from field-collected larvae was positively correlated with the $\mathrm{NO}_{3}^{-}$concentration in the lake, but not at temperatures below $10^{\circ} \mathrm{C}$. This shows that $\mathrm{N}_{2} \mathrm{O}$ emission from the larvae is stimulated by $\mathrm{NO}_{3}^{-}$availability in the macroenvironment (i.e., the water column), but only above a certain temperature threshold somewhere around $4-10^{\circ} \mathrm{C}$.

The lack of stimulation of $\mathrm{N}_{2} \mathrm{O}$ emission by $\mathrm{NO}_{3}^{-}$at low temperatures cannot be explained by the lower availability of $\mathrm{NO}_{3}^{-}$inside the burrow, which is predicted by numerical simulations made for laboratory-incubated larvae based on their ventilation activity, because the $\mathrm{NO}_{3}^{-}$concentrations measured in the gut and hemolymph were similar to those in the water column (see below). Instead, the low metabolic activity of the larvae and/or the bacteria in the gut at $4{ }^{\circ} \mathrm{C}$ may serve as an explanation (Bairlein 1989). At low temperature, the feeding activity of C. plumosus larvae is very low and the gut residence time is very long (i.e., $32 \mathrm{~h}$ at $5^{\circ} \mathrm{C}$; Johnson et al. 1989). As a consequence, the rates of denitrification and $\mathrm{N}_{2} \mathrm{O}$ production may become limited by dissolved organic substrates instead of $\mathrm{NO}_{3}^{-}$available in the gut. Second, the gut contents of $C$. plumosus larvae might be not fully anoxic and thus not conducive to denitrification at $4^{\circ} \mathrm{C}$ (Stief and Eller 2006).

At $15^{\circ} \mathrm{C}$ and $21^{\circ} \mathrm{C}$, the rate of $\mathrm{N}_{2} \mathrm{O}$ emission increased with $\mathrm{NO}_{3}^{-}$concentration and leveled off between 250 and $500 \mu \mathrm{mol} \mathrm{L}{ }^{-1} \mathrm{NO}_{3}^{-}$, suggesting limitation of gut denitrification by dissolved organic substrates or living bacterial biomass. The larvae take up organic substrates and bacterial biomass by feeding on detritus particles trapped in a net inside the burrow (Walshe 1947), whereas $\mathrm{NO}_{3}^{-}$ might be taken up actively by feeding and/or passively by ion transport across the integument (Neumann et al. 2001). Because passive uptake of $\mathrm{NO}_{3}^{-}$would be uncoupled from 
active uptake of organic substrates and bacterial biomass, there could be a surplus of $\mathrm{NO}_{3}^{-}$in the gut that cannot further increase the rate of denitrification.

The rate of $\mathrm{N}_{2} \mathrm{O}$ emission from $C$. plumosus larvae kept in laboratory microcosms also increased with temperature, but only at $\mathrm{NO}_{3}^{-}$concentrations above $50 \mu \mathrm{mol} \mathrm{L}^{-1}$ in the water column. Similar stimulation by temperature was observed for the field-collected larvae, but only at $\mathrm{NO}_{3}^{-}$ concentrations above $25 \mu \mathrm{mol} \mathrm{L} \mathrm{L}^{-1}$ in the water column. Clearly, gut denitrification in laboratory-incubated larvae was limited by $\mathrm{NO}_{3}^{-}$availability in the gut at concentrations of 10 and $50 \mu \mathrm{mol} \mathrm{L}^{-1} \mathrm{NO}_{3}^{-}$in the water column and therefore could not be enhanced by increased temperature. Above $50 \mu \mathrm{mol} \mathrm{L}^{-1} \mathrm{NO}_{3}^{-}$in the water column, the $\mathrm{N}_{2} \mathrm{O}$ emission rate increased exponentially with temperature, and the $\mathrm{Q}_{10}$ values calculated for the temperature range 4 $21^{\circ} \mathrm{C}$ were 2.2 and 2.3 for 250 and $500 \mu \mathrm{mol} \mathrm{L}^{-1} \mathrm{NO}_{3}^{-}$, respectively. These are typical values for sedimentary denitrification (Rysgaard et al. 2004).

Taken together, $\mathrm{NO}_{3}^{-}$concentration and temperature stimulated larval $\mathrm{N}_{2} \mathrm{O}$ emission apparently only when they both exceeded certain threshold values. Such a mutual influence of $\mathrm{NO}_{3}^{-}$availability and temperature is also known for sedimentary denitrification and $\mathrm{N}_{2} \mathrm{O}$ emission (Jørgensen and Sørensen 1985; Inwood et al. 2005; Wall et al. 2005), and thus probably reflects the physiological control of denitrifying bacteria by these two variables.

Ventilation activity vs. $\mathrm{O}_{2}$ and $\mathrm{NO}_{3}^{-}$availability-C. plumosus larvae live in U-shaped burrows that may reach several decimeters deep into the sediment (Hilsenhoff 1966). The larva ventilates its burrow periodically by undulatory body movements to gain suspended food particles and $\mathrm{O}_{2}$. Along with $\mathrm{O}_{2}, \mathrm{NO}_{3}^{-}$is transported into the burrow, where it is consumed by microbial processes in the surrounding sediment. To understand the coupling between the $\mathrm{NO}_{3}^{-}$ availability in the water column and the burrow due to the counteracting effects of burrow ventilation and denitrification activity in the burrow walls, we implemented a numerical model that takes into account the temporal aspects of larval ventilation as well as the inhibition of bacterial denitrification by $\mathrm{O}_{2}$. This was done because $\mathrm{NO}_{3}^{-}$concentrations inside the burrow could not be measured directly.

The numerical simulations suggest that the ventilation by the larva is likely triggered by a threshold $\mathrm{O}_{2}$ concentration inside the burrow. As implied by the modeled $\mathrm{O}_{2}$ profiles along the burrow at the end of the average resting interval (Fig. 7A), the triggering concentrations are similar at $15^{\circ} \mathrm{C}$ and $21^{\circ} \mathrm{C}$, but are considerably lower at $4^{\circ} \mathrm{C}$. This difference is mainly due to the disproportionately prolonged RPs observed at $4{ }^{\circ} \mathrm{C}$ (Fig. 5B), indicating that the lower temperature significantly decreased the physiological $\mathrm{O}_{2}$ demand of the larvae (Bairlein 1989). Simulations also show that by combining the relatively fast pumping rates and several-minute-long pumping intervals (Fig. 5), the larvae are able to effectively replenish $\mathrm{O}_{2}$ concentrations inside the burrow to levels close to those in the overlying water ( $>70 \%$; Fig. 7A) even if burrows are up to $50 \mathrm{~cm}$ long.
Periodic ventilation by the larva also results in fluctuating $\mathrm{NO}_{3}^{-}$concentrations inside the burrow (Fig. 8). Although the simulated range of fluctuations depended on the distance along the burrow, the concentrations were always above $50 \%$ of the water column level even for a several-decimeters-long burrow. The exception was at $4{ }^{\circ} \mathrm{C}$, where $\mathrm{NO}_{3}^{-}$in deeper parts of the burrow (e.g., $>30 \mathrm{~cm}$ ) decreased below $20 \%$ of the water column level at the end of the average RP (Fig. 7B). This implies that if the $\mathrm{NO}_{3}^{-}$ concentrations in the gut and hemolymph are directly coupled to the $\mathrm{NO}_{3}^{-}$available in the immediate surroundings of the larva, the bacteria in the gut are not expected to be limited by $\mathrm{NO}_{3}^{-}$as a consequence of denitrification activity in the sediment surrounding the burrow, except perhaps at low temperatures. This would be true regardless of whether the coupling occurs instantaneously or over time scales comparable to or larger than the typical pumping or resting intervals.

Interestingly, $\mathrm{NO}_{3}^{-}$concentrations measured directly in the gut and hemolymph of $C$. plumosus larvae kept in laboratory microcosms were similar to or sometimes even higher than those in the water column, which was true for all investigated temperatures (Fig. 3). This suggests that $\mathrm{NO}_{3}^{-}$in the gut and hemolymph is in fact decoupled from the $\mathrm{NO}_{3}^{-}$available in the immediate surroundings of the larva, which is predicted to be fluctuating. Alternative sources of $\mathrm{NO}_{3}^{-}$inside the larva or the burrow, if existing, would reconcile the predicted $\mathrm{NO}_{3}^{-}$availability and the measured $\mathrm{NO}_{3}^{-}$concentrations. Nitrate production in the larvae via NO dioxygenation mediated by hemoglobin (Gardner et al. 2006) could be one such possibility. This pathway converts the signaling molecule and stress hormone $\mathrm{NO}$ to $\mathrm{NO}_{2}^{-}$and $\mathrm{NO}_{3}^{-}$in vertebrate and several invertebrate species (Gardner 2005; Angelo et al. 2008), but has not yet been reported for C. plumosus. Alternatively, $\mathrm{NO}_{3}^{-}$in the gut and hemolymph may originate from ingested and digested microorganisms that store $\mathrm{NO}_{3}^{-}$ intracellularly. Also, nitrification inside the burrow stimulated by larval $\mathrm{NH}_{4}^{+}$excretion could be a possible additional source of $\mathrm{NO}_{3}^{-}$for the larvae. However, the probability that any of these processes would lead to equal $\mathrm{NO}_{3}^{-}$concentrations in the water column and in the larva (Fig. 3) is rather low. Moreover, it is not clear whether any of these processes could quantitatively provide the internal $\mathrm{NO}_{3}^{-}$surplus measured at $21^{\circ} \mathrm{C}$. Thus, a conceptually different mechanism needs to be considered to explain the observed high $\mathrm{NO}_{3}^{-}$concentrations in the gut and hemolymph of the larva. It can be speculated that $\mathrm{NO}_{3}^{-}$ is stored by the larvae during phases of high $\mathrm{NO}_{3}^{-}$ concentrations inside the burrow (e.g., at the end of pumping intervals). The sink constituted by the larva and its gut bacteria is not significant to deplete the internal $\mathrm{NO}_{3}^{-}$during a typical RP. For example, considering a typical size of the larva (radius $1 \mathrm{~mm}$, length $2 \mathrm{~cm}$ ), the maximum observed $\mathrm{N}_{2} \mathrm{O}$ production rate of 122 pmol ind. ${ }^{-1} \mathrm{~h}^{-1}$ would translate to the depletion of the internal $\mathrm{NO}_{3}^{-}$on the order of $4 \mu \mathrm{mol} \mathrm{L}-1$ during a RP of $1 \mathrm{~h}$, which is very little compared to the high $\mathrm{NO}_{3}^{-}$concentrations measured in this study. However, $\mathrm{NO}_{3}^{-}$storage by 
chironomid larvae is not supported by any prior evidence and requires further investigation.

Environmental implications - The annual cycle of the potential rates determined for field-collected C. plumosus larvae revealed phases with positive and negative rates. Considering all field data, the net contribution of $C$. plumosus to the overall annual $\mathrm{N}_{2} \mathrm{O}$ emission from Lake Engelsholm was estimated at 10.5 pmol ind. ${ }^{-1} \mathrm{~h}^{-1}$. The highest (73 pmol ind. $\left.{ }^{-1} \mathrm{~h}^{-1}\right)$ and lowest ( -27 pmol ind. ${ }^{-1}$ $\mathrm{h}^{-1}$ ) rates were measured in May and January, respectively. A similar annual pattern was found for the larvae of the mayfly Ephemera danica that live in sandy stream sediments (P. Stief and A. Schramm unpubl.). There, the maximum rate of $\mathrm{N}_{2} \mathrm{O}$ emission determined during spring was 2.5 -fold higher than the average annual rate. Based on the average annual $\mathrm{N}_{2} \mathrm{O}$ emission rate of field-collected C. plumosus larvae of 10.5 pmol ind. ${ }^{-1} \mathrm{~h}^{-1}$ and assuming a high, but not uncommon, larval density of 5000 ind. $\mathrm{m}^{-2}$ in lake sediment (Fukuhara and Sakamoto 1987; Soster and McCall 1990), gut denitrification of the C. plumosus population will produce $0.46 \mathrm{mmol} \mathrm{m}^{-2} \mathrm{yr}^{-1}$ of $\mathrm{N}_{2} \mathrm{O}$. This corresponds to $7.5-175 \%$ of $\mathrm{N}_{2} \mathrm{O}$ emission rates reported from sediment of lakes in which $C$. plumosus might reach high densities (Mengis et al. 1997; Svensson 1998; Liikanen et al. 2003). In contrast, if the maximum $\mathrm{N}_{2} \mathrm{O}$ emission rate determined under laboratory conditions (i.e., $122 \mathrm{pmol}$ $\mathrm{N}_{2} \mathrm{O}$ ind. ${ }^{-1} \mathrm{~h}^{-1}$ at $21^{\circ} \mathrm{C}$ and $500 \mu \mathrm{mol} \mathrm{L} \mathrm{L}^{-1} \mathrm{NO}_{3}^{-}$) were used, gut denitrification by C. plumosus populations of the same density would annually produce $5.33 \mathrm{mmol} \mathrm{m}^{-2}$ of $\mathrm{N}_{2} \mathrm{O}$. It needs to be noted, however, that many lakes and reservoirs harbor densities of $C$. plumosus that are 1-2 orders of magnitude lower than used in our example (Real et al. 2000) and will therefore not exhibit a significant increase of their overall $\mathrm{N}_{2} \mathrm{O}$ emission because of the presence of $C$. plumosus larvae.

The laboratory incubations of the $C$. plumosus larvae revealed the potential of how much the $\mathrm{N}_{2} \mathrm{O}$ emissions from the guts of aquatic invertebrates could increase, should the environmental conditions change abruptly or gradually. For instance, heavy storms cause spates and sudden increases of $\mathrm{NO}_{3}^{-}$concentrations in the water column (Rusjan et al. 2008), and may thus drastically stimulate the $\mathrm{N}_{2} \mathrm{O}$ emission rate when $\mathrm{NO}_{3}^{-}$concentrations are normally low (e.g., during warm summer and autumn months). Second, the projected increase in global temperature will increase the frequency of warm winters, potentially also leading to an increase in the $\mathrm{N}_{2} \mathrm{O}$ emission rates due to simultaneously higher temperatures and higher wet deposition of atmospheric $\mathrm{NO}_{3}^{-}$(Hole et al. 2008).

Modeling implications - By their ventilation activity, $C$. plumosus larvae supply $\mathrm{NO}_{3}^{-}$from the water column to denitrifiers living in the sediment in close proximity of the burrow. Stimulation of denitrification inside chironomid burrows as well as $\mathrm{N}_{2} \mathrm{O}$ emission from burrows by this mechanism has been shown before (Pelegri and Blackburn 1995; Svensson 1998; Stief et al. 2009). However, it has not been recognized until now that $C$. plumosus larvae are able to supply $\mathrm{NO}_{3}^{-}$to the maximum depth of their burrows
( $\sim 50 \mathrm{~cm}$; Hilsenhoff 1966). In many eutrophic lakes, the densities of $C$. plumosus larvae reach several thousands of individuals per square meter (Fukuhara and Sakamoto 1987; Soster and McCall 1990). Thus, a dense and considerably deep 3-dimensional network of burrows, which are frequently flushed with $\mathrm{NO}_{3}^{-}$from the water column by the ventilation activity of $C$. plumosus larvae, must exist in the sediments of these habitats. We suggest that diagenetic models, such as those developed by Meile et al. (2003) or Lewandowski and Hupfer (2005), need to incorporate these burrow networks as well as the highly dynamic input and microbial utilization of $\mathrm{NO}_{3}^{-}$and other solutes to more accurately describe the biochemical exchange processes between sediments and the overlying water.

\section{Acknowledgments}

We thank Torben Wiis (Danish Ministry of the Environment, Environmental Center Ribe) for access to Lake Engelsholm and unpublished $\mathrm{NO}_{3}^{-}$data. We are grateful to Gaby Eickert, Ines Schröder, and Tove Wiegers for technical assistance. The manuscript benefited from reviews by Dirk De Beer and two anonymous referees. Financial support was provided through a Marie Curie Fellowship of the European Union to P.S. (grant 515536), a Danish Research Agency Grant to A.S. (grant 2117-050027), European Union Project "Dynamic sensing of chemical pollution disasters and predictive modeling of their spread and ecological impact" granted to L.P. (grant 518043-1), and the Max Planck Society (Germany).

\section{References}

Angelo, M., A. Hausladen, D. J. Singel, and J. S. Stamler. 2008. Interactions of NO with hemoglobin: From microbes to man, p. 131-168. In R. K. Poole [ed.], Globins and other nitric oxide-reactive proteins. Pt. A. Academic.

BAIRlein, F. 1989. The respiration of Chironomus-larvae (Diptera) from deep and shallow waters under environmental hypoxia and at different temperatures. Arch. Hydrobiol. 115: $523-536$.

Bergethon, P. R. 1998. The physical basis of biochemistry: The foundations of molecular biophysics. Springer.

Braman, R. S., and S. A. Hendrix. 1989. Nanogram nitrite and nitrate determination in environmental and biological materials by vanadium(III) reduction with chemiluminescence detection. Anal. Chem. 61: 2715-2718.

Brand, A., C. Dinkel, and B. Wehrli. 2009. Influence of the diffusive boundary layer on solute dynamics in the sediments of a seiche-driven lake: A model study. J. Geophys. Res. 114: G01010, doi:10.1029/2008JG000755.

Broecker, W. S., and T. H. Peng. 1974. Gas exchange between air and sea. Tellus 26: 21-35.

Dahnke, K., E. Bahlmann, And K. Emeis. 2008. A nitrate sink in estuaries? An assessment by means of stable nitrate isotopes in the Elbe estuary. Limnol. Oceanogr. 53: 1504-1511.

Deines, P., J. Grey, H. H. Richnow, and G. Eller. 2007. Linking larval chironomids to methane: Seasonal variation of the microbial methane cycle and chironomid $d^{13} \mathrm{C}$. Aquat. Microb. Ecol. 46: 273-282.

Fukuhara, H., and M. SaKamoto. 1987. Enhancement of inorganic nitrogen and phosphate release from lake sediment by tubificid worms and chironomid larvae. Oikos 48: $312-320$ 
GARDNER, P. R. 2005. Nitric oxide dioxygenase function and mechanism of flavohemoglobin, hemoglobin, myoglobin and their associated reductases. J. Inorg. Biochem. 99: 247-266.

—, A. M. Gardner, W. T. Brashear, T. Suzuki, A. N. Hvitved, K. D. R. Setchell, and J. S. Olson. 2006. Hemoglobins dioxygenate nitric oxide with high fidelity. J. Inorg. Biochem. 100: 542-550.

Hilsenhoff, W. L. 1966. The biology of Chironomus plumosus (Diptera: Chironomidae) in Lake Winnebago, Wisconsin. Ann. Entomol. Soc. Am. 59: 465-473.

Hole, L. R., H. A. DE Wit, AND W. Aas. 2008. Influence of summer and winter climate variability on nitrogen wet deposition in Norway. Hydrol. Earth Syst. Sci. 12: 405-414.

Horn, M. A., A. Schramm, and H. L. Drake. 2003. The earthworm gut: An ideal habitat for ingested $\mathrm{N}_{2} \mathrm{O}$ producing microorganisms. Appl. Environ. Microbiol. 69: 1662-1669.

Hymel, S. N., and C. J. Plante. 2000. Feeding and bacteriolytic responses of the deposit-feeder Abarenicola pacifica (Polychaeta: Arenicolidae) to changes in temperature and sediment food concentration. Mar. Biol. 136: 1019-1027.

Inwood, S. E., J. L. TANK, And M. J. Bernot. 2005. Patterns of denitrification associated with land use in 9 midwestern headwater streams. J. N. Am. Benthol. Soc. 24: 227-245.

Johnson, R. K., B. Boström, And W. J. VAn de Bund. 1989. Interactions between Chironomus plumosus L. and the microbial community in surficial sediments of a shallow eutrophic lake. Limnol. Oceanogr. 34: 992-1003.

Jørgensen, B. B., And J. Sørensen. 1985. Seasonal cycles of $\mathrm{O}_{2}$, $\mathrm{NO}_{3}^{-}$and $\mathrm{SO}_{4}^{2-}$ reduction in estuarine sediments: The significance of an $\mathrm{NO}_{3}^{-}$reduction maximum in spring. Mar. Ecol. Prog. Ser. 24: 65-74.

Kristensen, E., M. H. Jensen, and R. C. Aller. 1991. Direct measurement of dissolved inorganic nitrogen exchange and denitrification in individual Polychaete Nereis virens burrows. J. Mar. Res. 49: 355-378.

Leuchs, H. 1986. The ventilation activity of Chironomus larvae (Diptera) from shallow and deep lakes and the resulting water circulation in correlation to temperature and oxygen conditions. Arch. Hydrobiol. 108: 281-299.

Lewandowski, J., AND M. Hupfer. 2005. Effect of macrozoobenthos on two-dimensional small-scale heterogeneity of pore water phosphorus concentrations in lake sediments: A laboratory study. Limnol. Oceanogr. 50: 1106-1118.

Li, Y. H., and S. Gregory. 1974. Diffusion of ions in sea water and in deep-sea sediments. Geochim. Cosmochim. Acta 38: $703-714$.

LiIKANen, A., AND others. 2003. Spatial and seasonal variation in greenhouse gas and nutrient dynamics and their interactions in the sediments of a boreal eutrophic lake. Biogeochemistry 65: $83-103$.

Meile, C., K. Tuncay, and P. Van Cappellen. 2003. Explicit representation of spatial heterogeneity in reactive transport models: Application to bioirrigated sediments. J. Geochem. Explor. 78-79: 231-234.

Mengis, M., R. Gachter, and B. Wehrli. 1997. Sources and sinks of nitrous oxide $\left(\mathrm{N}_{2} \mathrm{O}\right)$ in deep lakes. Biogeochemistry 38: $281-301$.

Neumann, D., M. Kramer, I. Raschke, and B. Gräfe. 2001. Detrimental effects of nitrite on the development of benthic Chironomus larvae, in relation to their settlement in muddy sediments. Arch. Hydrobiol. 153: 103-128.
Nielsen, O. I., B. Gribsholt, E. Kristensen, and N. P. Revsbech. 2004. Microscale distribution of oxygen and nitrate in sediment inhabited by Nereis diversicolor: Spatial patterns and estimated reaction rates. Aquat. Microb. Ecol. 34: 23-32.

Pelegri, S. P., And T. H. Blackburn. 1995. Effect of bioturbation by Nereis sp., Mya arenaria and Cerastoderma sp. on nitrification and denitrification in estuarine sediments. Ophelia 42: 289-299.

Pina-Ochoa, E., and M. Alvarez-Cobelas. 2006. Denitrification in aquatic environments: A cross-system analysis. Biogeochemistry 81: 111-130.

Polerecky, L., N. Volkenborn, and P. Stief. 2006. High temporal resolution oxygen imaging in bioirrigated sediments. Environ. Sci. Technol. 40: 5763-5769.

Real, M., M. Rieradevall, and N. Prat. 2000. Chironomus species (Diptera: Chironomidae) in the profundal benthos of Spanish reservoirs and lakes: Factors affecting distribution patterns. Freshw. Biol. 43: 1-18.

Revsbech, N. P. 1989. An oxygen microsensor with a guard cathode. Limnol. Oceanogr. 34: 474 478.

Ricciardi, A., F. G. Whoriskey, and J. B. Rasmussen. 1997. The role of the zebra mussel (Dreissena polymorpha) in structuring macroinvertebrate communities on hard substrata. Can. J. Fish. Aquat. Sci. 54: 2596-2608.

Rusjan, S., M. Brilly, ANd M. Mikos. 2008. Flushing of nitrate from a forested watershed: An insight into hydrological nitrate mobilization mechanisms through seasonal high-frequency stream nitrate dynamics. J. Hydrol. 354: 187-202.

Rysgaard, S., R. N. Glud, N. Risgaard-Petersen, and T. DALSGAARD. 2004. Denitrification and anammox activity in Arctic marine sediments. Limnol. Oceanogr. 49: 1493-1502.

Soetaert, K., P. M. J. Herman, And J. J. Middelburg. 1996. A model of early diagenetic processes from the shelf to abyssal depths. Geochim. Cosmochim. Acta 60: 1019-1040.

Sommer, U. 1989. Nutrient status and nutrient competition of phytoplankton in a shallow, hypertrophic lake. Limnol. Oceanogr. 34: 1162-1173.

Soster, F. M., and P. L. McCall. 1990. Benthos response to disturbance in Western Lake Erie-field experiments. Can. J. Fish. Aquat. Sci. 47: 1970-1985.

Stief, P., AND D. De BeER. 2002. Bioturbation effects of Chironomus riparius on the benthic $\mathrm{N}$-cycle as measured using microsensors and microbiological assays. Aquat. Microb. Ecol. 27: 175-185.

— AND - 2006. Probing the microenvironment of freshwater sediment macrofauna: Implications of depositfeeding and bioirrigation for nitrogen cycling. Limnol. Oceanogr. 51: 2538-2548.

, AND G. ElLER. 2006. The gut microenvironment of sediment-dwelling Chironomus plumosus larvae as characterised with $\mathrm{O}_{2}, \mathrm{pH}$, and redox microsensors. J. Comp. Physiol. B 176: 673-683.

, M. Poulsen, L. P. Nielsen, H. Brix, and A. Schramm. 2009. Nitrous oxide emission by aquatic macrofauna. Proc. Natl. Acad. Sci. USA 106: 4296-4300.

Svensson, J. M. 1998. Emission of $\mathrm{N}_{2} \mathrm{O}$, nitrification and denitrification in a eutrophic lake sediment bioturbated by Chironomus plumosus. Aquat. Microb. Ecol. 14: 289-299.

, AND L. LeONARDSON. 1996. Effects of bioturbation by tube-dwelling chironomid larvae on oxygen uptake and denitrification in eutrophic lake sediments. Freshw. Biol. 35: 289-300. 
Sweerts, J. P. R. A., And D. De Beer. 1989. Microelectrode measurements of nitrate gradients in the littoral and profundal sediments of a meso-eutrophic lake (Lake Vechten, The Netherlands). Appl. Environ. Microbiol. 55: 754-757.

Wall, L. G., J. L. Tank, T. V. Royer, and M. J. Bernot. 2005. Spatial and temporal variability in sediment denitrification within an agriculturally influenced reservoir. Biogeochemistry 76: $85-111$.

Walshe, B. M. 1947. Feeding mechanisms of Chironomus larvae. Nature 160: 474-476.

Wang, F., A. Tessier, And L. Hare. 2001. Oxygen measurements in the burrows of freshwater insects. Freshw. Biol. 46: 317-327.
Wright, J. F., P. D. Hiley, And A. D. Berrie. 1981. A 9-year study of the life cycle of Ephemera danica Mull (Ephemeridae, Ephemeroptera) in the River Lambourn, England. Ecol. Entomol. 6: 321-331.

Associate editor: Ronnie Nøhr Glud

Received: 01 June 2009

Accepted: 25 November 2009 Amended: 13 November 2009 